\section{Bioaccumulation of Selected Toxic Heavy Metals in Mastacembelus armatus from Three Rivers of Malakand Division, Pakistan}

\author{
Hazrat Ali ${ }^{1,2 *}$ and Ezzat Khan ${ }^{1 *}$ \\ ${ }^{1}$ Department of Chemistry, University of Malakand, Chakdara 18800, Dir Lower, \\ Khyber Pakhtunkhwa, Pakistan \\ ${ }^{2}$ Green and Environmental Chemistry, Ecotoxicology and Ecology Laboratory, \\ Department of Zoology, University of Malakand, Chakdara 18800, Dir Lower, \\ Khyber Pakhtunkhwa, Pakistan
}

\begin{abstract}
A B S T R A C T
Contamination of water bodies with toxic heavy metals is a genuine environmental problem. Bioaccumulation of toxic heavy metals in fish poses a potential health risk to fish consumers including humans. The aim of present research work was to study the bioaccumulation of $\mathrm{Cr}, \mathrm{Ni}, \mathrm{Cd}$ and $\mathrm{Pb}$ in the carnivorous fish Mastacembelus armatus at different sites of three rivers in Malakand Division, Pakistan. The study also investigated tissue-specific accumulation of these metals in M. armatus at one site of River Panjkora. Concentrations of $\mathrm{Cr}, \mathrm{Ni}, \mathrm{Cd}$ and $\mathrm{Pb}$ in the fish muscles ranged from $10.2 \pm 3.5$ to $29.8 \pm 17.3$, $24.7 \pm 13.1$ to $104.5 \pm 27.1,0.77 \pm 0.17$ to $2.4 \pm 0.12$ and $7.5 \pm 5.3$ to $75.2 \pm 41.0 \mathrm{mg} \mathrm{kg}^{-1}$ wet weight, respectively. The order of metal accumulation in different tissues of $M$. armatus was: kidneys $>$ liver $\cong$ skin $>$ muscles $>$ gills. Bioaccumulation factor (BAF) values of the metals in muscles of $M$. armatus were in the order: $\mathrm{Cr}>\mathrm{Pb}>\mathrm{Ni}>\mathrm{Cd}$. BAF values show that these metals are accumulated in the fish tissues and may pose a potential health risk to regular consumers.
\end{abstract}

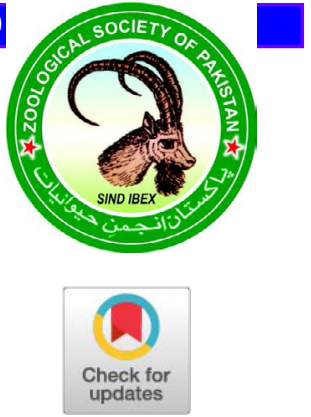

Article Information Received 08 July 2017 Revised 24 June 2018 Accepted 27 August 2019 Available online 05 May 2021

Authors' Contribution

EK and HA conceived and designed the study. HA collected, prepared and analyzed the samples. HA analyzed the data and wrote the manuscript. EK supervised the research work.

Key words

Bioaccumulation, Environmental pollution, Health risk, Heavy metals, Mastacembelus armatus

\section{INTRODUCTION}

E nvironmental pollution is one of the environmental challenges faced by human society (Ali and Khan, 2017). Heavy metals are defined as "naturally occurring metals having atomic number $(Z)$ greater than 20 and an elemental density greater than $5 \mathrm{~g} \mathrm{~cm}^{-3}$ " (Ali and Khan, 2018b). A rapid increase in pollution of waters by metals is promoted by industrial and agricultural development. After release into the environment, heavy metals do not biodegrade, but rather accumulate in the environment and living organisms (Stankovic et al., 2014). Even the essential heavy metals can also be harmful to biota and cause adverse health effects at high concentrations (Mahboob et al., 2014; Stankovic et al., 2014). At high concentrations, toxic heavy metals can generate reactive oxygen species (ROS) and thus induce oxidative stress (Waheed et al., 2014). Contamination of freshwater fish with toxic heavy metals is an issue of environmental, ecological and economic importance and has scope for

\footnotetext{
* Corresponding author: hazratali@uom.edu.pk; hazrataliuom@gmail.com; ekhan@uom.edu.pk 0030-9923/2021/0004-1251 \$ 9.00/0

Copyright 2021 Zoological Society of Pakistan
}

public health (Ali and Khan, 2018a). Since fish muscles are the primary edible part, they can cause serious health risks to fish consumers (Waheed et al., 2014). Fish dwelling in contaminated waters should be used in diet with caution (Javed and Usmani, 2016).

Exposure to $\mathrm{Cr}$ causes oxidative stress with subsequent possible cellular and molecular damages such as genotoxic and carcinogenic effects (Junaid et al., 2016). Exposure to $\mathrm{Ni}$ causes hematological effects in animals and humans. Its many harmful effects are due to its interference with the metabolism of essential metal ions like $\mathrm{Mg}^{2+}, \mathrm{Ca}^{2+}, \mathrm{Mn}^{2+}$, $\mathrm{Fe}^{2+}, \mathrm{Cu}^{2+}$ and $\mathrm{Zn}^{2+}$ (Cempel and Nikel, 2006). Exposure to $\mathrm{Cd}$ at low levels initially causes renal tubular dysfunction, and finally ends in itai-itai disease (Nogawa, 1984). There is also an association between such an exposure and increased risk of osteoporosis (Alfvén et al., 2000). Cadmium has endocrine disruptive effects and affects synthesis of sexual steroids even at quite low concentrations (Knazicka et al., 2015). Lead is a toxic metal and its extensive use has created environmental contamination and health problems throughout the world (Rehman et al., 2015). Heavy metal pollution in water bodies also has adverse effects on the aquatic organisms. It has been reported that heavy metalscontaining wastewater in river has induced stress in the fish Channa punctatus, making them weak and susceptible 
to diseases (Javed and Usmani, 2015).

In Pakistan, water pollution has become a serious problem with rapidly increasing industrialization. Industrial effluents as well as domestic sewage are continuously discharged into rivers. These discharges contain toxic heavy metals. Such discharges into Pakistani rivers have adversely affected freshwater fisheries (Javed, 2005). Industrially polluted waters are currently discharged into water bodies without pretreatment (Rehman et al., 2008). It has been reported that aquatic chemical pollution in River Kabul is most probably one of the major causes of the rapid population decline of the endangered freshwater fish Tor putitora in the river (Yousafzai and Shakoori, 2011). In a recent study (Ali et al., 2017), bioaccumulation of the essential heavy metals $\mathrm{Cu}$ and $\mathrm{Zn}$ was investigated in Schizothorax plagiostomus and Mastacembelus armatus from the study area. The aim of the present research work was to study the bioaccumulation of four toxic heavy metals, $\mathrm{Cr}, \mathrm{Ni}, \mathrm{Cd}$ and $\mathrm{Pb}$ in muscles of the economically important fish species Mastacembelus armatus in three rivers of Malakand Division, Pakistan. This fish species was selected because it is commercially important and preferred by consumers in the study area. Tissue-specific bioaccumulation of the selected heavy metals was also studied in M. armatus at Khazana on River Panjkora. We selected muscle tissue for quantification of metals because this is the tissue of main interest for routine monitoring of environmental metal contamination (Yousafzai et $a l ., 2012$ ) and is the most important in terms of human consumption.

\section{MATERIALS AND METHODS}

\section{Study area and fish species}

This research work was conducted along River Swat, River Panjkora, and River Barandu in Malakand Division of Khyber Pakhtunkhwa province of Pakistan. The study fish, tire-track spiny eel or zig-zag eel (Mastacembelus armatus), a common fish species of the Indian subcontinent, is an economically important fish.

\section{Sample collection, preparation and analysis}

Three specimens of $M$. armatus were collected at each sampling site on the three rivers. Thus, twenty-one individuals of the fish were collected in total from all sites in the study area. The collected fish were transported to the laboratory in ice on the same day. Samples were prepared for metal analysis through wet digestion method using concentrated acids $\mathrm{HNO}_{3}$, and $\mathrm{HClO}_{4}$. Fish samples were processed on wet weight basis. Muscle tissue samples, free of skin, were taken from behind the dorsal fin, above the lateral line; also recently reported by Rosseland et al.
(2017). For tissue-specific bioaccumulation study, tissues were separated by fish dissection. Water samples were prepared according to Malik and Maurya (2014), while the fish samples were digested according to Javed and Usmani (2016) with modifications: For acid digestion, 1.0 g sample of fish tissue was placed in a $100 \mathrm{~mL}$ beaker, 7.5 $\mathrm{mL} \mathrm{HNO}_{3}$ and $2.5 \mathrm{~mL} \mathrm{HClO}_{4}$ were added to it. The sample was heated on a hot plate at $80 \mathrm{C}$ until the evolution of brown fumes of $\mathrm{NO}_{2}$ ceased and a clear yellow solution was obtained. The solution was allowed to cool at room temperature and then filtered through a $0.45 \mu \mathrm{m}$ filter paper. The filtrate was diluted to a final volume of $50 \mathrm{~mL}$ with analyte-free water. The selected heavy metals were determined in the prepared samples by Flame Atomic Absorption Spectrophotometer (Perkin-Elmer Model No. 2380). Quality control check was performed in order to assure the accuracy of the metal analysis (Supplementary Table I).

\section{Statistical analyses}

For each experimental analysis, three samples i.e., three individual fish specimens were used. Results are shown as mean \pm standard deviation (SD). Results were analyzed with the statistical software SPSS version 23.0. Different statistical tests such as analysis of variance (ANOVA), and correlation were used for comparing and analyzing the results. $P$ value of 0.05 was considered for statistical significance.

\section{RESULTS AND DISCUSSION}

The concentrations of the four heavy metals in muscles of the study fish species from River Swat, River Panjkora and River Barandu are shown in Table I. One Way ANOVA (Tukey test) was used to compare concentrations of heavy metals at different sites on River Barandu. In most cases, the differences were statistically not significant, most probably due to small sample size and large standard deviation values in the results. The reason for large standard deviation values was the use of three individual fish specimens for each analysis instead of pooling tissues from three specimens and then taking three composite samples from the pooled tissues. Therefore, generally, we could not observe clear trends in concentrations of the selected heavy metals along river sites. However, in some cases, a clear trend could be seen. For example, in case of Ni bioaccumulation in the muscles of the study fish species, an increase was seen in concentration from upstream to downstream (Fig. 1).

Chromium concentrations found in this study in muscles of $M$. armatus ranged from $11.3 \pm 0.85$ to $29.8 \pm$ $17.3 \mathrm{mg} \mathrm{kg}^{-1} \mathrm{ww}$ from River Swat, $1280.2 \pm 600.0$ from 
River Panjkora while $10.2 \pm 3.5$ to $21.8 \pm 10.6$ from River Barandu. Siraj et al. (2014) have reported bioaccumulation of heavy metals in two fish species, Aorichthys seenghala and Ompok bimaculatus near Nowshera on River Kabul, Pakistan. Their reported $\mathrm{Cr}$ concentrations in muscles of these two fish are $565.3 \pm 148.7$ and $703.0 \pm 125.3 \mu \mathrm{g} \mathrm{g}^{-1}$ ww respectively. Ngelinkoto et al. (2014) have reported highest $\mathrm{Cr}$ concentration of $8.6 \mathrm{mg} \mathrm{kg}^{-1} \mathrm{ww}$ in muscles of some fish species from Kwilu-Ngongo River, Congo. Javed and Usmani (2011) have reported $\mathrm{Cr}$ concentration of $1.0 \pm 0.56 \mathrm{mg} \mathrm{kg}^{-1} \mathrm{dw}$ in muscles of Clarias gariepinus collected from Rasalganj fish market, Aligarh, India. They did not detect $\mathrm{Cr}$ in muscles of two other fish, Channa punctatus and Labeo rohita in the same collection. A comparison of our results with these studies shows that $\mathrm{Cr}$ concentrations from our study are lower than those of the first mentioned study and higher than those of the latter two studies. Cr concentration in muscles of $M$. armatus at Khazana site of River Panjkora (1280.2 $\pm 600.0 \mathrm{mg} \mathrm{kg}^{-1}$ ww) was unusually high and was beyond expectation.

Table I. Heavy metal concentrations in muscles of Mastacembelus armatus collected from three rivers of Malakand Division.

\begin{tabular}{lllll}
\hline Site & \multicolumn{4}{c}{ Metal concentration $\left(\mathrm{mg} \mathrm{kg}^{-1}\right.$ wet weight) } \\
\cline { 2 - 5 } & $\mathbf{C r}$ & $\mathbf{N i}$ & $\mathbf{C d}$ & $\mathbf{P b}$ \\
\hline River Swat & & & \\
Kabal & $29.8 \pm 17.3$ & $34.2 \pm 20.1$ & $0.77 \pm 0.17$ & $32.0 \pm 34.0$ \\
Chakdara & $11.3 \pm 0.85$ & $24.7 \pm 13.1$ & $1.4 \pm 0.62$ & $75.2 \pm 41.0$ \\
River Panjkora & & & \\
Khazana & $1280.2 \pm 600.0$ & $39.2 \pm 27.3$ & $2.4 \pm 0.12$ & $40.2 \pm 28.0$ \\
River Barandu & & & \\
Toor & $10.2 \pm 3.5$ & $25.5^{\mathrm{b}} \pm 15.1$ & $1.4 \pm 0.29$ & $19.0 \pm 1.1$ \\
Warsak & & & & \\
Elai & $21.8 \pm 10.6$ & $32.2^{\mathrm{b}} \pm 5.1$ & $0.83 \pm 0.10$ & $28.8 \pm 12.3$ \\
Daggar & $12.3 \pm 4.8$ & $38.7^{\mathrm{b}} \pm 23.7$ & $1.2 \pm 0.33$ & $16.3 \pm 14.6$ \\
Dewana & $10.3 \pm 4.0$ & $104.5^{\mathrm{a}} \pm 27.1$ & $1.2 \pm 0.53$ & $7.5 \pm 5.3$ \\
Baba & & & & \\
\hline
\end{tabular}

Results are shown as mean \pm standard deviation $(n=3)$. Mean values in a column with different superscript letters are significantly different at $\mathrm{p}$ $\leq 0.05$ (One Way ANOVA, Tukey Test).

Nickel concentrations found in this study in muscles of $M$. armatus ranged from $24.7 \pm 13.1$ to $34.2 \pm 20.1 \mathrm{mg}$ $\mathrm{kg}^{-1}$ ww from River Swat, 39.2 \pm 27.3 from River Panjkora while $25.5 \pm 15.1$ to $104.5 \pm 27.1$ from River Barandu. Siraj et al. (2014) have reported bioaccumulation of $\mathrm{Ni}$ in Aorichthys seenghala and Ompok bimaculatus collected near Nowshera from River Kabul, Pakistan. Their reported
$\mathrm{Ni}$ concentrations in muscles of these two fish are $94.7 \pm$ 33.3 and $135.0 \pm 52.6 \mu \mathrm{g} \mathrm{g}^{-1}$ ww respectively. Previously, Ahmad et al. (2014) have not detected Ni in muscles of Schizothorax plagiostomus collected from three different sites on River Panjkora. Ngelinkoto et al. (2014) have reported highest $\mathrm{Ni}$ concentration of $6.4 \mathrm{mg} \mathrm{kg}^{-1}$ ww in muscles of some fish species from Kwilu-Ngongo River, Congo. In a recent study, Javed and Usmani (2016) have reported $\mathrm{Ni}$ concentration of $59.0 \pm 0.06 \mathrm{mg} \mathrm{kg} \mathrm{kg}^{-1}$ $\mathrm{dw}$ in muscles of $M$. armatus collected from a thermal power plant effluent-polluted canal in Aligarh, India. In another study, Javed and Usmani (2011) have reported $\mathrm{Ni}$ concentrations of $34.1 \pm 1.4,21.0 \pm 1.7$ and $10.8 \pm 2.0$ $\mathrm{mg} \mathrm{kg} \mathrm{kg}^{-1} \mathrm{dw}$ in muscles of Channa punctatus, Clarias gariepinus and Labeo rohita collected from Rasalganj fish market, Aligarh, India. A comparison of our results with these studies shows that our reported concentrations are lower than those of the first mentioned study except $\mathrm{Ni}$ concentration in muscles of $M$. armatus at Dewana Baba site of River Barandu (104.5 $\left.\pm 27.1 \mathrm{mg} \mathrm{kg}^{-1} \mathrm{ww}\right)$. Furthermore, our reported Ni concentrations are higher than that of Ngelinkoto et al. (2014) and comparable to those of the latter two studies.

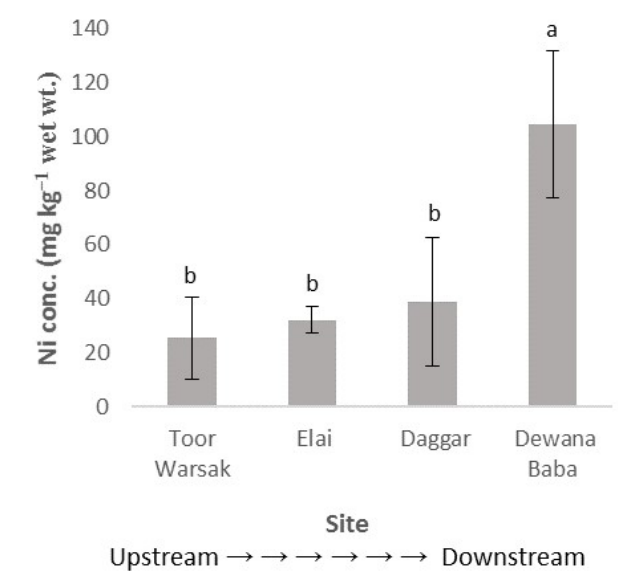

Fig. 1. Ni concentrations (mg kg-1 wet weight) in muscles of Mastacembelus armatus at different sites of River Barandu.

Cadmium concentrations found in this study in muscles of $M$. armatus ranged from $0.77 \pm 0.17$ to 1.4 $\pm 0.62 \mathrm{mg} \mathrm{kg}^{-1}$ ww from River Swat, $2.4 \pm 0.12$ from River Panjkora while $0.83 \pm 0.10$ to $1.4 \pm 0.29$ from River Barandu. Siraj et al. (2014) have reported bioaccumulation of $\mathrm{Cd}$ in Aorichthys seenghala and Ompok bimaculatus collected near Nowshera from River Kabul, Pakistan. Their reported $\mathrm{Cd}$ concentrations in muscles of these two fish are $60.7 \pm 17.2$ and $71.7 \pm 12.1 \mu \mathrm{g} \mathrm{g}^{-1} \mathrm{ww}$ respectively. 
Previously, Ahmad et al. (2014) have not detected Cd in muscles of Schizothorax plagiostomus collected from three different sites on River Panjkora. A comparison of our results with these studies shows that our reported $\mathrm{Cd}$ concentrations are very low as compared to those of the first mentioned study.

Lead concentrations found in this study in muscles of M. armatus ranged from $32.0 \pm 34.0$ to $75.2 \pm 41.0 \mathrm{mg}$ $\mathrm{kg}^{-1}$ ww from River Swat, $40.2 \pm 28.0$ from River Panjkora while $7.5 \pm 5.3$ to $28.8 \pm 12.3$ from River Barandu. Siraj et al. (2014) have reported bioaccumulation of $\mathrm{Pb}$ in Aorichthys seenghala and Ompok bimaculatus collected near Nowshera from River Kabul, Pakistan. Their reported $\mathrm{Pb}$ concentrations in muscles of these two fish are $350.7 \pm$ 37.2 and $407.0 \pm 126.6 \mu \mathrm{g} \mathrm{g}^{-1} \mathrm{ww}$ respectively. Previously, Ahmad et al. (2014) have reported $\mathrm{Pb}$ concentrations of $0.01,0.03$ and $0.09 \mu \mathrm{g} \mathrm{g}^{-1}$ in muscles of Schizothorax plagiostomus at upstream, sewage-release and downstream sites respectively on River Panjkora. Ngelinkoto et al. (2014) have reported highest $\mathrm{Pb}$ concentration of $6.0 \mathrm{mg}$ $\mathrm{kg}^{-1} \mathrm{ww}$ in muscles of some fish species from KwiluNgongo River, Congo. A comparison of our results with these studies shows that our reported $\mathrm{Pb}$ concentrations are lower than those of the first mentioned study and higher than those of the latter two studies.

The relatively high accumulation of $\mathrm{Pb}$ in muscles of the study fish from River Swat and River Panjkora may be due to discharge of this metal into the river water from different anthropogenic sources such as industrial effluents, combustion of fossil fuels and application of phosphate fertilizers. The relatively high accumulation of $\mathrm{Ni}$ in the fish downstream in case of River Barandu may be due to discharge of marble industry effluents into the river water. However, release of different heavy metals into natural waters from natural sources especially from weathering of mafic and ultramafic rocks is also very important.

M. armatus is a carnivorous fish and may accumulate higher concentrations of potentially toxic heavy metals from its diet. Afrin et al. (2015) have reported highest concentrations of heavy metals i.e., $\mathrm{Cr}, \mathrm{Cd}$ and $\mathrm{Pb}$ in $M$. armatus among three available fish species from River Turag, Bangladesh. Ahmad et al. (2014) have reported that presently, the water and fish of River Panjkora are safe for human consumption. Likewise, recently, Ullah et al. (2016a) have reported that River Panjkora is less polluted compared to other rivers in Pakistan. However, they have communicated that presently, the river is facing sewage burden and the continued pollution from such discharge in the river may ultimately lead to serious concerns in the future. River Barandu is also being polluted by effluents from marble industries in Buner (Khan et al., 2012). Recently, Mulk et al. (2016) have found decreased ichthyofaunal diversity near marble industry effluents in River Barandu.

Table II. Correlation of the selected heavy metals in different tissues of Mastacembelus armatus collected at Khazana site from River Panjkora.

\begin{tabular}{llllll}
\hline Tissue & Metal & \multicolumn{4}{c}{ Pearson Correlation Coefficient } \\
\cline { 3 - 6 } & & Cr & Ni & Cd & Pb \\
\hline Muscles & $\mathrm{Cr}$ & 1 & & & \\
& $\mathrm{Ni}$ & 0.794 & 1 & & \\
& $\mathrm{Cd}$ & -0.992 & -0.713 & 1 & \\
Gills & $\mathrm{Pb}$ & -0.757 & $-0.998^{*}$ & 0.671 & 1 \\
& $\mathrm{Cr}$ & 1 & & & \\
& $\mathrm{Ni}$ & -0.260 & 1 & & \\
& $\mathrm{Cd}$ & 0.079 & 0.942 & 1 & \\
& $\mathrm{~Pb}$ & 0.219 & 0.885 & 0.990 & 1 \\
Skin & $\mathrm{Cr}$ & 1 & & & \\
& $\mathrm{Ni}$ & -0.526 & 1 & & \\
& $\mathrm{Cd}$ & -0.587 & $0.997 *$ & 1 & \\
& $\mathrm{~Pb}$ & -0.816 & 0.921 & 0.947 & 1 \\
Liveryyyy & $\mathrm{Cr}$ & 1 & & & \\
& $\mathrm{Ni}$ & 0.820 & 1 & & \\
& $\mathrm{Cd}$ & 0.827 & 0.355 & 1 & \\
& $\mathrm{~Pb}$ & 0.956 & 0.616 & 0.955 & 1 \\
Kidneys & $\mathrm{Cr}$ & 1 & & & \\
& $\mathrm{Ni}$ & -0.382 & 1 & & \\
& $\mathrm{Cd}$ & -0.705 & 0.924 & 1 & \\
& $\mathrm{~Pb}$ & -0.740 & 0.904 & $0.999 *$ & 1 \\
\hline
\end{tabular}

*: Correlation is significant at the 0.05 level (2-tailed).

Tissue-specific bioaccumulation of HMs in Mastacembelus armatus

The concentrations of the four heavy metals in different tissues of M. armatus are shown in Figure 2. From Figure 2, it is seen that the order of metal accumulation in different tissues of the fish is: muscles $>$ kidneys $>$ skin $>$ liver $>$ gills for $\mathrm{Cr}$; kidneys $>$ liver $>$ skin $>$ muscles $>$ gills for Ni; kidneys $>$ liver $=$ skin $>$ muscles $>$ gills for $\mathrm{Cd}$ and finally kidneys $>$ liver $\cong$ skin $>$ muscles $>$ gills for $\mathrm{Pb}$. Thus generally, the order of metal accumulation is: kidneys $>$ liver $\cong$ skin $>$ muscles $>$ gills except for $\mathrm{Cr}$ where muscles have the highest accumulation. The general pattern of heavy metal accumulation observed in this study can be expected because kidneys and liver are metabolically active tissues and accumulate comparatively higher concentrations of toxic heavy metals for storage, sequestration and detoxification. It has been reported that 
among fish tissues, liver accumulates relatively more quantities of heavy metals (Vinodhini and Narayanan, 2008). Rauf et al. (2009) have reported higher accumulation of $\mathrm{Cd}$ and $\mathrm{Cr}$ in fish liver and minimum accumulation in gills. Similarly, Javed and Usmani (2013) have observed highest heavy metal load in liver while least in skin of $M$. armatus collected from a rivulet at Kasimpur, Aligarh, India. Ullah et al. (2016b) have reported tissue-specific bioaccumulation of heavy metals in three fish species from River Panjkora, Pakistan. They have observed the order of heavy metal bioaccumulation in different tissues as liver $>$ kidneys $>$ muscles $>$ gills. Malik et al. (2014) have reported relatively higher concentrations of heavy metals in liver, kidneys and gills compared to those in skin and muscles of four edible fish species i.e., Tor putitora, Cirrhinus mrigala, Labeo calbasu and Channa punctatus from Rawal Lake Reservoir, Pakistan.
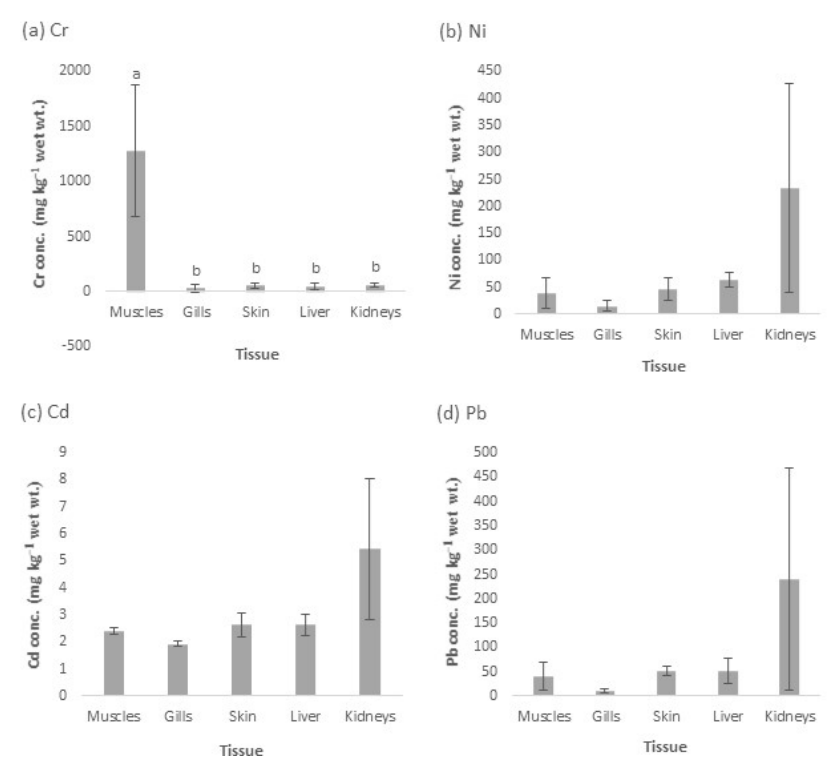

Fig. 2. Heavy metal concentrations ( $\mathrm{mg} \mathrm{kg}^{-1}$ wet weight) in different tissues of Mastacembelus armatus at Khazana site on River Panjkora.

In a previous study, Javed and Usmani (2013) have investigated the bioaccumulation of heavy metals in different tissues of $M$. armatus collected from a rivulet at Kasimpur, Aligarh, India. Their reported Ni concentrations in gills, liver, kidneys, muscles and skin were $200.0 \pm 1.7$, $450.0 \pm 0.06,149.3 \pm 0.50,59.0 \pm 0.09$ and $45.1 \pm 0.02$ $\mathrm{mg} \mathrm{kg}{ }^{-1} \mathrm{dw}$ respectively. Our reported Ni concentrations in different tissues of $M$. armatus are comparable with these results. In a recent study, Rosseland et al. (2017) have reported $\mathrm{Cr}, \mathrm{Ni}, \mathrm{Cd}$ and $\mathrm{Pb}$ concentrations in gills and liver of M. armatus from Lake Phewa, Nepal. They have reported that in gills, the concentrations of these metals were 0.7-1.0, 2.3-3.8, 0-1.3 and 0.3-0.6 $\mu \mathrm{g} \mathrm{g}^{-1}$ $\mathrm{dw}$ respectively while in liver the corresponding metal concentrations were $0.1-0.5,0-0.2,0.1-2.5$ and $0-0.8 \mu \mathrm{g}$ $\mathrm{g}^{-1} \mathrm{dw}$ respectively, which are lower than our reported metal concentrations. Yousafzai and Shakoori (2008) have studied bioaccumulation of some heavy metals including $\mathrm{Cr}, \mathrm{Ni}$ and $\mathrm{Pb}$ in gills of Tor putitora at three sites of River Kabul, Pakistan. Their reported $\mathrm{Cr}$ concentrations in gills at a reference site and two polluted sites, site 1 and site 2 , were $5.3 \pm 0.18,6.6 \pm 0.07$ and $6.0 \pm 0.38 \mu \mathrm{g}$ $\mathrm{g}^{-1} \mathrm{ww}$ respectively. The corresponding Ni concentrations were $53.3 \pm 8.4,128.0 \pm 8.8$ and $133.0 \pm 7.3 \mu \mathrm{g} \mathrm{g}^{-1} \mathrm{ww}$ respectively while the corresponding $\mathrm{Pb}$ concentrations were $219.3 \pm 31.4,313.7 \pm 29.9$ and $321.0 \pm 9.8 \mu \mathrm{g} \mathrm{g}{ }^{-1}$ ww respectively. A comparison of our results with these values shows that our reported $\mathrm{Cr}$ concentration in gills is higher than these values while our reported $\mathrm{Ni}$ and $\mathrm{Pb}$ concentrations in gills are lower than these values.

Correlation analysis was performed to check the correlation among the selected heavy metals in different tissues of $M$. armatus. Results of this analysis are shown in Table II. By looking at this table, it can be seen that significant correlations were found between $\mathrm{Pb}$ and $\mathrm{Ni}$ in muscles $(\mathrm{R}=-0.998)$, between $\mathrm{Cd}$ and $\mathrm{Ni}$ in skin $(\mathrm{R}=$ $0.997)$ and between $\mathrm{Pb}$ and $\mathrm{Cd}$ in kidneys $(\mathrm{R}=0.999)$.

\section{Calculation of bioaccumulation factor (BAF)}

The bioaccumulation of the selected heavy metals in different tissues of $M$. armatus was also quantified by calculating the bioaccumulation factor (BAF). This factor is the ratio of the concentration of a heavy metal in a given tissue of a fish to the concentration of that heavy metal in the water in which the fish dwells. It is calculated by using the following equation (Javed and Usmani, 2013):

$$
B A F=\frac{\text { Concentration of } H M \text { in fish tissue }\left(\mathrm{mg} \mathrm{kg}^{-1} \text { dry weight }\right)}{\text { Concentration of HM in water }\left(\mathrm{mg} \mathrm{L}^{-1}\right)}
$$

Table III gives BAF values of the selected heavy metals in different tissues of $M$. armatus collected from Khazana site on River Panjkora. Concentrations of the four heavy metals were determined in the water of River Panjkora at this site and are given in Table III. Concentrations of heavy metals in different tissues on wet weight basis were converted to their concentrations on dry weight basis assuming moisture content as $75 \%$ of wet weight, as considered by Ikemoto et al. (2008) for $\mathrm{Cd}, \mathrm{Pb}$ and $\mathrm{Hg}$ in an aquatic food web study in the Mekong Delta, South Vietnam. In a previous study, Javed and Usmani (2013) have reported BAF values of some heavy metals including $\mathrm{Ni}$ in different tissues of $M$. armatus collected from a polluted rivulet at Kasimpur, Aligarh, India. Their reported BAF values of $\mathrm{Ni}$ in muscles, gills, skin, liver and 
kidneys of this fish were 491.5, 1666.7, 375.5, 3749.7 and 1244.4 respectively. Comparing these values with those in Table III shows that all these values are higher than those in our study except for BAF in kidneys. Javed and Usmani (2013) have reported high BAF values in liver for all the studied heavy metals. In our study, we found highest BAF values in kidneys for all the selected heavy metals except $\mathrm{Cr}$, whose $\mathrm{BAF}$ value was highest in muscles.

Table III. Bioaccumulation factor (BAF) values of the selected heavy metals in different tissues of Mastacembelus armatus at Khazana site on River Panjkora.

\begin{tabular}{lllllll}
\hline \multirow{2}{*}{$\begin{array}{l}\text { Heavy } \\
\text { metal }\end{array}$} & $\begin{array}{l}\text { Conc. in } \\
\text { water }\left(\mathbf{m g ~ L}^{-1}\right)\end{array}$ & \multicolumn{5}{c}{ BAF } \\
\cline { 3 - 7 } & & Muscles & Gills & Skin & Liver & Kidneys \\
\hline $\mathrm{Cr}$ & 0.367 & 13839.7 & 311.7 & 582.0 & 520.8 & 668.5 \\
$\mathrm{Ni}$ & 0.594 & 264.1 & 104.6 & 312.0 & 429.8 & 1573.0 \\
$\mathrm{Cd}$ & 0.041 & 234.2 & 188.3 & 256.6 & 256.6 & 529.8 \\
$\mathrm{~Pb}$ & 0.227 & 707.8 & 182.0 & 910.5 & 907.5 & 4228.4 \\
\hline
\end{tabular}

\section{CONCLUSIONS}

Results of the study showed that metal concentrations in muscles of the study fish from the three rivers were comparable. Generally, clear trends could not be observed for metal concentrations at different sites of the rivers when going from upstream to downstream. However, Ni concentrations in fish muscles at different sites on River Barandu show a clear pattern of increase downstream. This may be due to contamination of the river water by wastewaters from marble industries. Tissue-specific accumulation in different tissues of $M$. armatus showed the order as: kidneys $>$ liver $\cong$ skin $>$ muscles $>$ gills. BAF values of the metals in different tissues of $M$. armatus show that these metals are accumulated from the river in the fish muscles and may pose a potential health risk to regular consumers.

\section{ACKNOWLEDGEMENTS}

The authors are thankful to Prof. Dr. Rup Lal, Professor at Department of Zoology, University of Delhi, India, for gifting a copy of standard literature keys for fish identification and to Mr. Abdur Rahman, Lecturer in Zoology, and Fisheries Specialist at Department of Zoology, University of Malakand, for his help in fish identification. The authors are also thankful to Dr. Muhammad Anwar Sajad, Department of Botany, Islamia College Peshawar, for his cooperation in metal analysis.
Supplementary material

There is supplementary material associated with this article. Access the material online at: https://dx.doi. org/10.17582/journal.pjz/20170708190719

\section{Statement of conflict of Interest}

The authors declare that there is no conflict of interests regarding the publication of this article.

\section{REFERENCES}

Afrin, R., Mia, M.Y., Ahsan, M.A. and Akbor, A., 2015. Concentration of heavy metals in available fish species (Bain, Mastacembelus armatus; Taki, Channa punctatus and Bele, Glossogobius giuris) in the Turag River, Bangladesh. Pak. J. Scient. Indust. Res. Ser. Biol. Sci., 58: 104-110.

Ahmad, K., Azizullah, A., Shama, S. and Khattak, M.N.K., 2014. Determination of heavy metal contents in water, sediments, and fish tissues of Shizothorax plagiostomus in river Panjkora at Lower Dir, Khyber Pakhtunkhwa, Pakistan. Environ. Monitor. Assess., 186: 7357-7366. https:// doi.org/10.1007/s10661-014-3932-1

Alfvén, T., Elinder, C.G., Carlsson, M.D., Grubb, A., Hellström, L., Persson, B., Pettersson, C., Spång, G., Schütz, A. and Järup, L., 2000. Lowlevel cadmium exposure and osteoporosis. $J$. Bone Mineral Res., 15: 1579-1586. https://doi. org/10.1359/jbmr.2000.15.8.1579

Ali, H., Ali, W., Ullah, K., Akbar, F., Ahrar, S., Ullah, I., Ahmad, I., Ahmad, A., Ilahi, I. and Sajad, M.A., 2017. Bioaccumulation of $\mathrm{Cu}$ and $\mathrm{Zn}$ in Schizothorax plagiostomus and Mastacembelus armatus from River Swat, River Panjkora and River Barandu in Malakand Division, Pakistan. Pakistan J. Zool., 49: 1555-1561. https://doi.org/10.17582/ journal.pjz/2017.49.5.1555.1561

Ali, H. and Khan, E., 2017. Environmental chemistry in the twenty-first century. Environ. Chem. Lett., 15: 329-346. https://doi.org/10.1007/s10311-0160601-3

Ali, H. and Khan, E., 2018a. Assessment of potentially toxic heavy metals and health risk in water, sediments, and different fish species of River Kabul, Pakistan. Hum. Ecol. Risk Assess., 24: 2101-2118. https://doi.org/10.1080/10807039.2018.1438175

Ali, H. and Khan, E., 2018b. What are heavy metals? Long-standing controversy over the scientific use of the term 'heavy metals' - proposal of a comprehensive definition. Toxicol. Environ. Chem., 100: 6-19. https://doi.org/10.1080/02772248.2017 


\section{.1413652}

Cempel, M. and Nikel, G., 2006. Nickel: a review of its sources and environmental toxicology. Polish $J$. environ. Stud., 15: 375-382.

Ikemoto, T., Tu, N.P.C., Okuda, N., Iwata, A., Omori, K., Tanabe, S., Tuyen, B.C. and Takeuchi, I., 2008. Biomagnification of trace elements in the aquatic food web in the Mekong Delta, South Vietnam using stable carbon and nitrogen isotope analysis. Arch. environ. Contam. Toxicol., 54: 504-515. https://doi.org/10.1007/s00244-007-9058-5

Javed, M., 2005. Heavy metal contamination of freshwater fish and bed sediments in the river Ravi stretch and related tributaries. Pak. J. biol. Sci., 8: 1337-1341. https://doi.org/10.3923/ pjbs.2005.1337.1341

Javed, M. and Usmani, N., 2011. Accumulation of heavy metals in fishes: a human health concern. Int J. environ. Sci., 2: 671-682.

Javed, M. and Usmani, N., 2013. Assessment of heavy metal $(\mathrm{Cu}, \mathrm{Ni}, \mathrm{Fe}, \mathrm{Co}, \mathrm{Mn}, \mathrm{Cr}, \mathrm{Zn})$ pollution in effluent dominated rivulet water and their effect on glycogen metabolism and histology of Mastacembelus armatus. SpringerPlus, 2: Article No. 390. https://doi.org/10.1186/2193-1801-2390

Javed, M. and Usmani, N., 2015. Stress response of biomolecules (carbohydrate, protein and lipid profiles) in fish Channa punctatus inhabiting river polluted by thermal power plant effluent. Saudi J. Biol. Sci., 22: 237-242. https://doi.org/10.1016/j. sjbs.2014.09.021

Javed, M. and Usmani, N., 2016. Accumulation of heavy metals and human health risk assessment via the consumption of freshwater fish Mastacembelus armatus inhabiting, thermal power plant effluent loaded canal. SpringerPlus, 5: Article No. 776. https://doi.org/10.1186/s40064-016-2471-3

Junaid, M., Hashmi, M.Z., Malik, R.N. and Pei, D.S., 2016. Toxicity and oxidative stress induced by chromium in workers exposed from different occupational settings around the globe: A review. Environ. Sci. Pollut. Res., 23: 20151-20167. https://doi.org/10.1007/s11356-016-7463-x

Khan, Z.R., Haq, F., Ullah, R. and Ullah, M.I., 2012. The analysis of water samples in different industrialization units of District Buner, Khyber Pakhtunkhwa, Pakistan. Int. J. Biosci., 2: 82-85.

Knazicka, Z., Forgacs, Z., Lukacova, J., Roychoudhury, S., Massanyi, P. and Lukac, N., 2015. Endocrine disruptive effects of cadmium on steroidogenesis: Human adrenocortical carcinoma cell line NCI-
H295R as a cellular model for reproductive toxicity testing. J. Environ. Sci. Hlth. Part A., 50: 348-356. https://doi.org/10.1080/10934529.2015.987520

Mahboob, S., Al-Balwai, H.F.A., Al-Misned, F., AlGhanim, K.A. and Ahmad, Z., 2014. A study on the accumulation of nine heavy metals in some important fish species from a natural reservoir in Riyadh, Saudi Arabia. Toxicol. Environ. Chem., 96: 783-798. https://doi.org/10.1080/02772248.2014. 957485

Malik, D.S. and Maurya, P.K., 2014. Heavy metal concentration in water, sediment, and tissues of fish species (Heteropneustis fossilis and Puntius ticto) from Kali River, India. Toxicol. Environ. Chem., 96: 1195-1206. https://doi.org/10.1080/02772248 .2015 .1015296

Malik, R.N., Hashmi, M.Z. and Huma, Y., 2014. Heavy metal accumulation in edible fish species from Rawal Lake Reservoir, Pakistan. Environ. Sci. Pollut. Res., 21: 1188-1196. https://doi. org/10.1007/s11356-013-1992-3

Mulk, S., Korai, A.L., Azizullah, A. and Khattak, M.N.K., 2016. Decreased fish diversity found near marble industry effluents in River Barandu, Pakistan. Ecotoxicology, 25: 132-140. https://doi. org/10.1007/s10646-015-1575-9

Ngelinkoto, P., Thevenon, F., Devarajan, N., Birane, N., Maliani, J., Buluku, A., Musibono, D., Mubedi, J.I. and Poté, J., 2014. Trace metal pollution in aquatic sediments and some fish species from the KwiluNgongo River, Democratic Republic of Congo (Bas-Congo). Toxicol. environ. Chem., 96: 48-57. https://doi.org/10.1080/02772248.2014.910211

Nogawa, K., 1984. Cadmium. In: Changing metal cycles and human health (ed. J.O. Nriagu). Dahlem Konferenzen, Berlin, pp. 275-284. https://doi. org/10.1007/978-3-642-69314-4_16

Rauf, A., Javed, M. and Ubaidullah, M., 2009. Heavy metal levels in three major carps (Catla catla, Labeo rohita and Cirrhina mrigala) from the river Ravi, Pakistan. Pak. Vet. J., 29: 24-26.

Rehman, H.U., Farhan, Rehman, A., Khattak, B., Khaliq, A., Shams, S. and Atlas, A., 2015. Estimation of lead $(\mathrm{Pb})$ in the blood of road shopkeeper of KPK, Pakistan. World appl. Sci. J., 33: 1380-1382.

Rehman, W., Zeb, A., Noor, N. and Nawaz, M., 2008. Heavy metal pollution assessment in various industries of Pakistan. Environ. Geol., 55: 353-358. https://doi.org/10.1007/s00254-007-0980-7

Rosseland, B.O., Teien, H.-C., Basnet, S., Borgstrøm, R. and Sharma, C.M., 2017. Trace elements and organochlorine pollutants in selected fish species 
from Lake Phewa, Nepal. Toxicol. environ. Chem., 99: 390-401. https://doi.org/10.1080/02772248.20 16.1189915

Siraj, M., Shaheen, M., Sthanadar, A.A., Khan, A., Chivers, D.P. and Yousafzai, A.M., 2014. A comparative study of bioaccumulation of heavy metals in two fresh water species, Aorichthys seenghala and Ompok bimaculatous at River Kabul, Khyber Pakhtunkhwa, Pakistan. J. Biodiver. environ. Sci., 4: 40-54.

Stankovic, S., Kalaba, P., Stankovic, A.R., 2014. Biota as toxic metal indicators. Environ. Chem. Lett., 12: 63-84. https://doi.org/10.1007/s10311-013-0430-6

Ullah, S., Hasan, Z., Zuberi, A., 2016a. Heavy metals in three commercially valuable cyprinids in the river Panjkora, district Lower Dir, Khyber Pakhtunkhwa, Pakistan. Toxicol. environ. Chem., 98: 64-76. https:// doi.org/10.1080/02772248.2015.1100916

Ullah, S., Hussain, Z., Mahboob, S. and Al-Ghanim, K., 2016b. Heavy metals in Garra gotyla, Cyprinus carpio and Cyprinion watsoni from the River Panjkora, District Lower Dir, Khyber Pakhtunkhwa, Pakistan. Brazilian Arch. Biol. Technol., 59: e16160321. https://doi.org/10.1590/1678-43242016160321

Vinodhini, R. and Narayanan, M., 2008. Bioaccumulation of heavy metals in organs of fresh water fish Cyprinus carpio (Common carp). Int. J. environ. Sci. Technol., 5: 179-182. https://doi.org/10.1007/BF03326011

Waheed, S., Kamal, A. and Malik, R.N., 2014. Human health risk from organ-specific accumulation of toxic metals and response of antioxidants in edible fish species from Chenab River, Pakistan. Environ. Sci. Pollut. Res., 21: 4409-4417. https://doi. org/10.1007/s11356-013-2385-3

Yousafzai, A.M. and Shakoori, A.R., 2008. Heavy metal accumulation in the gills of an endangered South Asian fresh water fish as an indicator of aquatic pollution. Pakistan J. Zool., 40: 423-430.

Yousafzai, A.M. and Shakoori, A.R., 2011. Hepatic responses of a freshwater fish against aquatic pollution. Pakistan J. Zool., 43: 209-221.

Yousafzai, A.M., Siraj, M., Ahmad, H. and Chivers, D.P., 2012. Bioaccumulation of heavy metals in common carp: Implications for human health. Pakistan J. Zool., 44: 489-494. 